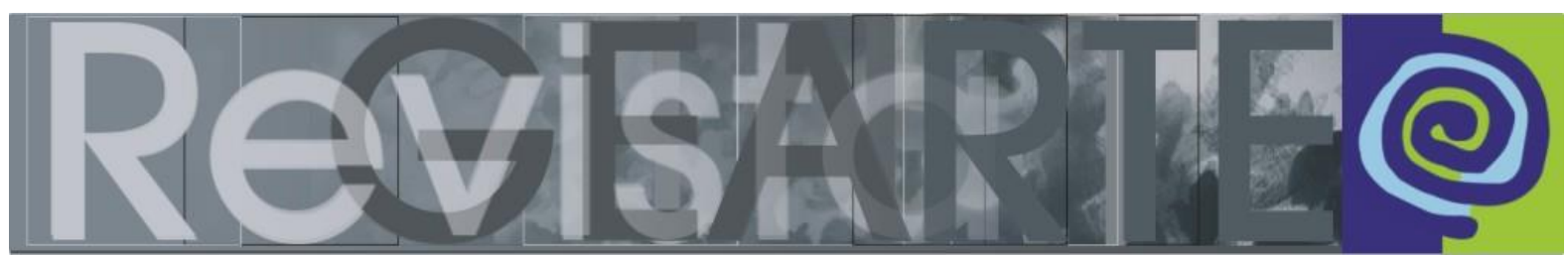

ISSN 2357-9854

\title{
El cuerpo joven como mito: una propuesta de antropología narrativa ${ }^{1}$
}

\author{
Otto Rosales Cárdenas (Universidad de los Andes — ULA, Táchira, Venezuela) \\ Stiver Machado Ramírez (Instituto Pedagógico Latinoamericano y Caribeño - \\ IPLAC, Havana, Cuba)
}

RESUMEN - El cuerpo joven como mito: una propuesta de antropología narrativa - El artículo propone la categoría el cuerpo joven como mito en un recorrido de autores para establecer el estudio exploratorio en la cultura juvenil expresada en los años sesenta del siglo XX. Tiene el propósito de mostrar la reflexión en tres dimensiones el movimiento del cuerpo como expresión juvenil. Tomando como base el cine, la moda y las sonoridades, se hace una exploración de la categoría a través de la categoría en el film "Simpatía por el diablo" de Jean Luc Godard, la minifalda y la hibridez musical que estructura el cruce de lenguajes en el film West Side Story (1961) de Robert Wise. Para sintetizar en una propuesta de antropología narrativa sobre la riqueza que presenta el estudio de la cultura urbana.

\section{PALABRAS CLAVE}

Cuerpo joven como mito. Cine. Moda. Sonoridades.

RESUMO - O corpo jovem como mito: uma proposta de antropologia narrativa $-\mathrm{O}$ artigo propõe a categoria do corpo jovem como mito através do estudo de alguns autores para estabelecer um estudo exploratório da cultura juvenil dos anos sessenta do século XX. Tem como propósito mostrar uma reflexão acerca do movimento do corpo como expressão juvenil em três dimensões. Ao tomar como base o cinema, a moda e as sonoridades, faz uma exploração da categoria corpo jovem no filme Simpatia pelo diabo de Jean Luc Godard, na minissaia e no hibridismo musical que estrutura o cruzamento de linguagens no filme West Side Story (1961) de Robert Wise. Para finalizar traz uma proposta de antropologia narrativa sobre a riqueza do estudo da cultura urbana.

PALAVRAS-CHAVE

Corpo jovem como mito. Cinema. Moda. Sonoridades.

\section{El cuerpo joven como mito}

Aproximarse a la categoría "El cuerpo joven como mito" nos permite apreciarla como el umbral entre un sujeto social que vive la tensión de una corporalidad humana finita, y un imaginario de juventud infinita, manifestada en una ilusión de vida eterna.

Tomando en consideración los cambios que experimenta el sujeto desde la niñez, hay infinidad de elementos que podrían perfilar las características de un cuerpo

1 El presente artículo representa un extracto de la tesis doctoral de Otto Rosales Cárdenas presentada y defendida en la Universidad de los Andes ULA - Mérida en el 2016. 
joven. Para este trabajo no recurrimos a datos demográficos ni médicos. Se trata de una categoría teórica, y por tanto más cercano a la metáfora que a la biología. Y sin embargo, no podemos olvidar que la biología, la materia corporal es imprescindible como elemento a incorporar en su lectura. La incorporamos desde el reconocimiento de una negación masiva a aceptar sus límites. Si el cuerpo es nuestro locus, el que nos ata a la tierra y por tanto constituye nuestro límite principal (FOUCAULT, 1966), estudiamos acá a un cuerpo que se convierte en espacio de subversión, de negación del tiempo y de la muerte. Espacio que la sociedad de consumo moldea sin límites y que al mismo tiempo constituye el principal espacio subjetivo de irreverencia contra la sociedad.

Un cuerpo que a la vez se construye bajo un imperio simbólico intenta burlar la vigilancia de las instituciones que lo albergan y moldean su comportamiento, escudriñando nuevos lenguajes en sus simbolizaciones, buscando refugio en la oferta del mercado, construyendo nuevas ritualidades transgresivas. Lo prohibido se incorpora y se muestra de manera provocadora en tatuajes, implantes, perforaciones, rapado, ídolos, pandillas, grupos musicales, prótesis tecnológicas; dispositivos y artefactos de desplazamientos y vértigo, trenes, motos, autos, parques de diversiones, cámaras, filmadores, video, cámaras fotográficas, espejos, internet, dispositivos, computadoras, redes sociales, drogas de estimulación, antidepresivos, estimulantes, bailes, discotecas, conciertos juveniles, revistas especializadas en moda, técnicas de recubrimiento, maquillaje, cirugías estéticas, lipoescultura...

Incorporando rituales ancestrales e imaginarios sagrados y profanos para diferenciarse de los adultos, y de su belleza convencional marcada por la invasión publicitaria. Esa infinitud corporal juvenil se desplaza en su prolongación hacia una tensión visual en la superficie del cuerpo, una infinitud de longevidad humana en donde la ilusión de lo eternamente joven asalta el mayor número de espectadores. El joven no desea llegar a la adultez y el adulto desea ilusoriamente quedarse con la imagen que irradian los jóvenes. La categoría el "cuerpo joven como mito" es el epicentro de una mesurada reflexión y revisión de los años sesenta (60) del siglo XX, expresado en el cine, la moda, las sonoridades. Y la intención del artículo es mostrar la importancia de aquella. 
Ciertamente partimos para interpretar y definir las culturas juveniles de la aproximación realizada por Michel Maffesoli y su término tribus urbanas ${ }^{2}$. Cuando reflexiona sobre la nueva participación de los jóvenes en la sociedad, el autor observa la fragmentación social y las nuevas emergencias de sectas ante las formas únicas de las imposiciones autoritarias de la sociedad. En una entrevista realizada por Luisa Corradini a Maffesoli en el año 2005 sobre el concepto de tribu urbana, ante la pregunta $-¿$ El antiguo contrato social ha sido reemplazado por la idea de pertenencia a un grupo, a una tribu? Señaló:

\begin{abstract}
Puede tratarse de tribus sexuales. Hay una multiplicidad de tribus sexuales que se muestran y se afirman: bisexuales, homosexuales, heterosexuales, etc. Pero también puede tratarse de tribus musicales (tecno, góticos, metal), artísticas, deportivas, culturales, religiosas. El desarrollo actual de las sectas es, desde ese punto de vista, muy significativo. Se trata, en realidad, de un proceso transversal. Allí donde el hombre moderno había instalado un cuerpo social absolutamente homogéneo - la República, única e indivisible -, nos encontramos hoy con una especie de fragmentación, de patchwork, con una constelación de grupos ${ }^{3}$.
\end{abstract}

Pareciera que los jóvenes buscan formas novedosas de participación en la sociedad y distanciarse de las organizaciones tradicionales. En la misma entrevista, Maffessoli plantea el concepto de nómade:

[...] es el hombre que va de una tribu a otra, que no tiene una única identidad ideológica, sexual, profesional o de clase, que no se deja encerrar dentro de roles que antes eran definitivos, en instituciones como el matrimonio. El nómade puede pertenecer simultáneamente a numerosas tribus (ibídem).

Esta reflexión permite focalizar la movilidad de la cultura juvenil y las maneras de participar en la sociedad, un desplazamiento de los jóvenes para no dejarse atrapar por las formas organizativas convencionales. Nos hace pensar que la cultura juvenil está en constante movilidad, de allí su difícil aprehensión.

Martín Barbero en "Pensar la Ciudad” citado por González y Gómez (1999, p. 165) señala:

2 Término utilizado por Maffesoli para caracterizar el retorno de lo arcaico en la cultura moderna occidental. Véase "El tiempo de las tribos" 2004.

3 Disponible en red: <http://www.lanacion.com.ar/734590-estamos-en-la-era-de-los-nomades-y-lastribus-dice-maffesoli>. 
La inversión de valores que ha positivizado la imagen de los jóvenes- al tiempo que desplaza y devalúa la experiencia de los saberes de los viejos- se halla asociada, de un lado, a cambio de fondo en los modos de producción y transmisión del saber y en los modos de sentir y juntarse que tienen uno de sus principales en la cultura tecnológica pero de otro lado, el nuevo valor de lo joven responde a una estratégica y global operación de mercado que ha hecho del joven un consumidor decisivo, y de la moda joven- ya sea en el vestido o en la música, en la bebida tipo Coca-Cola y las comidas rápidas o en buena parte de la parafernalia tecnológica: Walkman, video, video juegosel paradigma de lo moderno y lo actual, de lo bello y lo espontaneo, de lo fresco e innovador.

Deseamos resaltar entonces la paradoja de un sujeto individual que se mueve subversivamente en la cultura, para constituir el modelo ideal de la modernidad petrificada, cuyo signo es el movimiento. Estas consideraciones permitieron reflexionar la multiplicidad de elementos atribuibles al concepto de la cultura juvenil, utilizada para polemizar sobre la tensión del cuerpo joven como mito construido, en un imaginario que entra al cuerpo, se inscribe y escribe sus relatos míticos y sale a la sociedad del espectáculo.

Exploramos la categoría "el cuerpo joven como mito" en la cultura juvenil para una lectura en el cine, la moda y las sonoridades en la década de los años sesenta del siglo xx. Por cuanto permite ubicarla en un contexto donde el joven irrumpe en simbolizaciones irreverentes contra la cultura de la imposición del mercado del capital.

\section{El cine o el espejo juvenil}

Vista la modernidad como el resultado de agudas crisis que provocaron rupturas radicales en la estructura de la sociedad europea de finales del siglo XIX y comienzos del $\mathrm{XX}$, que progresivamente fue llevando a la sociedad hacia la racionalidad económica, ámbito dentro del cual los medios de comunicación van alcanzando el más alto grado de desarrollo tecnológico. Se puede describir como la sucesión de imágenes interconectadas, estructuradas artificialmente, fueron creando con ello un espejismo semejante al dejado por las luces de neón sobre una gran metrópolis (HURTADO, 1973).

En este contexto va surgiendo el cine como ilusión mítica, una construcción imaginaria que metamorfosea toda la vida social, en la cual el cuerpo joven como mito propende a ese delineamiento. Aquí el cuerpo y la corporeidad se miran como la 
resignificación de lo social y se centra la atención en la importancia que se les da al objeto simbolizado del consumo, una mercancía en el engranaje de la producción del capital.

De la reflexión sobre este fenómeno surgen propuestas tan valiosas como la de Morin (2001) quien desarrolla una mirada antropológica compleja, bajo la cual la imagen es la materia prima del cine y puente necesario entre la realidad objetiva y el mundo subjetivo, imaginario, del ser humano.

Para Morin (2001), el sujeto humano se resume como la cualidad psíquica alienada, el doble en el imaginario colectivo, ese "yo/otro, permaneciendo ajeno a mí, que no deja nunca de ser yo". Reclama una suerte de inmortalidad de permanencia, de transformaciones de él mismo. Se encarna en una imagen fija y móvil para asumirse en el cine como un juego de doble movimiento: por un lado, las cosas mismas a ser filmadas, lo cual lo dota de una extrema realidad inalcanzable por los otros sistemas nemotécnicos y, por otro, el movimiento del film. En esta relación entran en juego las facultades humanas; para el autor citado, el cine se convierte en tres elementos normalmente contradictorios: la magia, el sentimiento, la razón.

Las imágenes fílmicas y su juego de doble movimiento nos sirven en esta búsqueda de describir el cuerpo joven como mito, pues en el texto fílmico se muestra como una narración que se integran en el imaginario, el mito y el cuerpo.

La década de los años sesenta (60) del siglo XX, develó las metamorfosis ocasionadas y sufridas en el cuerpo del sujeto moderno que se hospedaron en la imagen juvenil. $\mathrm{Y}$ el cine ha sido escenario para develar los movimientos de los cuerpos, a través de ellos expresando el clima de ruptura e innovación que embarga la sociedad occidental.

El mundo occidental (básicamente Europa) está saliendo de la segunda guerra mundial, donde nuevas fuerzas hegemónicas como Francia, Inglaterra, y Estados Unidos imponen sus condiciones como vencedores en la contienda contra Alemania y Japón. Es esta una época donde todo parece contrariar la anhelada felicidad material. 
El individuo acosado por el imaginario de la guerra se vuelca entonces hacia la ciencia. El mito de la ciencia y su tecnología irradian promesas de poder, expresadas en la imagen del cuerpo joven, emprendedor, exitoso reflejadas en la imagen fílmica.

Pero no se puede olvidar que este es también un sujeto moderno que trae una experiencia pobre y desecha como consecuencia de la ruina del yo que le ha impuesto la guerra, la devastación de la naturaleza. Una atmósfera de pánico, una invasión del imaginario del mal a través del apocalipsis nuclear. Un imaginario del mal que se afianza como signo social narrándose como un mito de beligerancia a través de dioses destructores y paganos, en el que occidente juega constantemente sus reglas de imposición hacia nuestro cuerpo y en nuestra consciencia. En la reflexión de Hillman (2007, p. 23), la historia occidental nos ha dejado dos alternativas igualmente repugnantes. O bien adoramos a un dios "Pan" arcadio de una naturaleza sentimental que nos ofrece la liberación de esta historia, o bien lo maldecimos como un demonio pagano que amenaza a la civilización con su atavismo anárquico y otros excesos tales como oscuridad, representación, exhibicionismo o instinto primitivo.

Para este autor, se trata de regresar y pensar al dios "Pan" como un arquetipo instalado en el alma humana. Este giro nos permitiría superar o mirar con más cuidado las petrificaciones íntimas y leer nuestros movimientos psíquicos, en el contexto de una cultura monoteísta que niega y oculta la riqueza de un ancestral imaginario politeísta. "El Dios Pan ha muerto" dice Plutarco en su famoso Tratado citado por Hillman en su obra Pan y La Pesadilla (2007). Hillman elabora sobre la figura de Pan en torno a la expulsión del cuerpo en occidente. Nuestro grosero cuerpo material, o el viejo Pan asociado a la tierra y la animalidad. El imaginario de occidente alberga una tremenda contradicción, entre un cuerpo de piel áspera, con pezuñas, cuernos, y otro cuerpo maltratado, vejado, crucificado como lo es "El Cristo". Esta tensión marca uno de los trayectos más conflictivos de la sociedad moderna. El paso del politeísmo al monoteísmo dejó al cuerpo en la polaridad de las sombras, la oscuridad. Ese ángel de luz caído en la mítica judeo-cristiana, es quizá un resto del viejo "Pan" que no tiene otro lugar permitido en la cultura oficial.

López Pedraza (1980) también nos aproxima al dios "Pan" y lo ubica en la cultura de occidente como el dios del pánico máximo cuando su imagen se presenta 
bajo el ropaje histórico del diablo. El dios de las pesadillas, la epilepsia, la masturbación. El historiador francés J. Delumeau (1978) se refiere al universo de Pan enloquecido y pintado en la obra de Jerónimo Bosco, donde las pesadillas infernales alcanzan su mayor violencia en un imaginario estético que parece constantemente emprender occidente; como un espectro donde la alteridad se niega y resucita para autodestruirse y transparentarse como mal.

El cuerpo del sujeto moderno es repositorio de imágenes antiguas de horror: enfermedad, sangre, violencia, excrementos, sexualidad, envejecimiento, muerte. El cine ha mostrado y contribuido a construir este poderoso imaginario de juventud eterna y su contraparte de un cuerpo temido, odiado, deseado. Como medio de comunicación, magnifica, multiplica hasta el infinito, masifica y ensordece. Pero también puede y debe mostrar este discurso mítico revertido a través de un cine reflexivo y cuestionador, como es el cine de Jean-Luc Godard. En Simpatía por el diablo (1969), vale destacar las imágenes de Satán y sus distintos rostros, presentados en juego con el proceso de incubación de una pieza musical de una banda popular de música juvenil (the Rolling Stone), de contracultura para el momento, cargado de letras admonitorias y actitud rebelde contra un mundo enfrentado, mentiroso y cruel.

En toda la obra de Godard el enfrentamiento bélico es una constante. En sus obras posteriores adquiere una muestra cercana al horror. En su larga trayectoria ha explorado el lenguaje audiovisual como pocos, elaborando una propuesta estética desde los años sesenta hasta la actualidad. Una especie de técnica mosaico, un cine consciente de sí mismo y de su poder generador de ilusiones, donde el autor destaca complejidades como el fantasma de destrucción masiva mostrado en los escenarios de la guerra.

Al detenerse en el film Simpatía por el Diablo (1969) que presenta elementos que muestran el cuerpo joven como figura mitificada. La película habla de un héroe mítico a través de la corporeidad. La obra insiste en la gestualidad, indumentaria, oralidad, formas enunciativas, lenguajes, ritmos, ambiental, locaciones naturales y artificiales, dando una atmosfera que tensiona la categoría y la muestra a plenitud. 
Bajtín (1926) permite ampliar la reflexión en torno a la corporeidad y observarla como una metáfora gestual, entendiendo por gesto tanto la mímica como los gestos de la cara. Dice este autor que el gesto, al igual que la entonación, necesita del apoyo coral de los circundantes; solo en una atmósfera de apoyo social resulta posible un gesto libre y seguro. Por otra parte, el gesto, lo mismo que la entonación, abre la situación e introduce a un tercer participante, al héroe. En el gesto dormita siempre el germen de agresión o de defensa, de amenaza o de caricia, y al que contempla y oye se le asigna el papel de aliado o de testigo (BAJTíN, 1997, p. 121).

Para Metz (1972, p. 23), el héroe aparecerá en la filmografía con las características mencionadas por Bajtin (1926) y es en la obra cinematográfica de Godard donde se muestra a plenitud; permitiendo delinear un adolecente aceptado en el cine. Situando un perfil del joven desde los inicios del cine hasta la década de los años sesenta (60) del siglo XX, el cuerpo joven como mito surge en tipologías como: 1) El galán heroico superafectivo del cine mudo; 2) El joven respetuoso y correcto de los films rosa; 3) El granuja burlón que hace reír; 4) El descentrado de buen fondo de los Tramposos; 5) El horrible beatnik. En nuestra actualidad, podríamos agregar al héroe mártir en las barricadas y las muchedumbres rebeldes.

El héroe se delinea en la categoría el cuerpo joven como mito en un sujeto de contiendas callejeras, en las bandas musicales o el líder del barrio, en contiendas políticas. En el cine de Hollywood existen antecedentes con James Dean (Rebelde sin causa, 1955), Marlon Brando (Los jóvenes salvajes, 1961). En capitales europeas como Londres, Paris, o Roma las bandas juveniles despuntan a modo de nuevo fenómeno masivo en los centros urbanos. Del mismo modo acontece en las ciudades de América Latina.

Es decir, se perfilan grupos de jóvenes con indumentaria específica y un estilo determinado; cabello largo, lentes oscuros, botas de asalto, chaquetas negras, pulseras, bufandas, manoplas, anillos que visten y muestran el cuerpo de manera distinta, para diferenciarse de la masa o muchedumbre en los distintos sectores sociales de las capitales (estilo posteriormente masificado, parte importante de la paradoja que señalamos y que Godard advierte en su film). 
El centro de atención ahora es un héroe construido desde la publicidad, que edifica una imagen de ídolo musical. Que canta y baila a sus nuevos fanáticos su música. Un ídolo con su indumentaria bárbara, distinta, que no se parece a nadie, impone sus canciones a través de la radio, el cine, y los club nocturnos. La lista es amplia: Jhonny Halliday, Francoice Hardy, Sylvie Vartan, Salvatore Adamo, James Brown, Elvis Presley, Los Beatles, Los Rolling Stone... convirtiéndose en héroes míticos de las muchedumbres juveniles.

Godard ofrece en el film su técnica de discursos entretejidos en una estética cinematográfica muy personal, presentando al espectador la confusión de discursos amalgamados. Es una obra que perturba. Un cuerpo violento, el joven(a) sintetiza un héroe presentado de manera crítica y la narrativa de voz en off cuenta historietas, asociada con el fondo musical. No hay economía de lenguaje ni vacío para la contemplación, sino una agresiva profusión de elementos que elabora discurso sobre la sociedad a través de un collage que es la exacerbación de los contenidos presentados junto con sus opuestos y contradicciones. Y la selección resulta incómoda al espectador.

Es un cine que reflexiona permanentemente sobre estas asimetrías, en ese espacio intermedio que es la poesía y a la vez ensayo sobre la poesía. El cuerpo joven en Godard se muestra a través de una poética que entrecruza el amor, la política, lo gansteril, el mar, el sol; en Godard se desgarra el cuerpo para mostrarlo en su plena desnudez buscando acorralar fantasmas de una sociedad contemporánea que los oculta perversamente en sus significantes míticos.

\footnotetext{
Al igual que cada policía es un criminal/y los pecadores santos y cara o cruz es lo mismo, llámame simplemente Lucifer/porque necesito freno/ así que si me encuentras muestra un poco de cortesía, algo de simpatía y buen gusto/ usa tu bien aprendida educación o se perderá tu alma (estrofa No 7).
}

En esta melodía compuesta por la banda Rolling Stone y cantada por Jagger; el mito del dios "Pan" se despliega a plenitud con toda su fuerza, cae la máscara y su voz solicita simpatía para él. 


\section{La moda o el refugio del cuerpo juvenil}

Es importante reconocer ante todo una dificultad para definir la moda, evitando las simplificaciones, pues se trata de un fenómeno social total que no debe reducirse a un vector para explicarla. Se requiere de los distintos discursos de las ciencias humanas para dar cuenta de su importancia en la cultura contemporánea.

El vestir expone al cuerpo a una metamorfosis siempre posible, la moda de nuestra época se ha permitido "narrar" esta metamorfosis, narrarse a sí misma en cierto modo, ostentando, junto con sus signos exteriores, también los procesos culturales, a veces casi técnicos, que han dado lugar a dichos signos. Imitando a la farsa carnavalesca, la moda ha permitido la confusión de los roles sexuales, ha sacado a la superficie lo que estaba oculto (etiquetas, ropa interior, costuras), ha invertido la función de la cobertura de los tejidos, adoptando las transparencias, ha roto los equilibrios y la rígida funcionalidad del traje tradicional y del vestido ritual, ha adoptado la cita intertextual como técnica constante y, finalmente, ha convertido al cuerpo en discurso, en signo, en cosa (CALEFATO, 2007).

Se piensa en la moda como parte fundamental del imaginario construido en torno a las corporeidades juveniles. La moda se muestra en escenarios y gestualidades de la vida diaria. Es mucho más que simple reacción al deseo de novedad. Sobre este aspecto Lipovetsky (2004, p. 10-11) precisa que:

[...] La moda no puede ser identificada con la simple manifestación de las pasiones vanidosas o distintivas, sino que se convierte en una institución excepcional, altamente problemática, una realidad socio-histórica característica de occidente y de la propia modernidad [...]

La moda se halla al mando de nuestras sociedades. En menos de medio siglo, la seducción y lo efímero han llegado a convertirse en los principios organizativos de la vida colectiva moderna; vivimos en sociedades dominadas por la frivolidad, último eslabón de la aventura capitalista, democrática, individualista.

Observa Lipovetsky la moda como uno de los espejos sociales. Pareciera existir una empatía entre esta y, la que proponemos en el cuerpo joven como mito, para su apreciación constituiría un destino histórico singular: la negación del poder inmemorial 
del pasado tradicional, la fiebre moderna de las novedades, la celebración del presente social.

En nuestro caso particular, proponemos ver la moda - entre la multiplicidad de aristas posibles - como velos para cubrir y develarlo. Como estrategia de uniformización, es decir dominación y ocultamiento del cuerpo, fin ulterior de la sociedad occidental. Es una suerte de vestir para camuflar y esconder, mostrando. Aun así, el cuerpo se niega a ser reducido, atrapado en una sola narrativa. Pensar que el cuerpo joven como mito se asoma a través de sí es una forma novedosa de mostrarlo, como ente que se desplaza a través de estrategias inéditas para trasgredir las relaciones de poder (que siempre tienden a ocultarlo, invisibilizándolo aun exhibiéndolo). El cuerpo, y nuestro cuerpo joven mítico, se mueven en las estructuras del engranaje del mercado y se escurre entre ellas, contradictoriamente, con toda la ambigüedad que implica este doble juego.

Al deslizar la mirada sobre la moda en la década de los años 60 del siglo XX, podemos notar cómo se fractura el concepto de "alta costura". La estética de la gran clase y el encanto femenino, la delicadeza, esa estética de la gracia. Este concepto estético fue pulverizado por el desarrollo del sportwear, de las modas juveniles marginales y de los creadores de los prét-à-porter, propuestas que se dirigen a imaginar lo que se consideró legítimo, propio de la sociedad del consumo: revistas, spots publicitarios, perfumes, zapatos, cortes de cabello, tatuajes, maquillajes, implantes, piercing, uñas acrílicas. Se está en presencia de varios lenguajes que narran el cuerpo del joven.

La moda se acerca a la lógica del arte moderno, a su experimentación multidireccional y a su ausencia de regla estética común. Es la fragmentación del sistema de la moda (BARTHES, 1967). Esa individualidad se manifiesta en las contradicciones de su masificación, donde el cuerpo joven como mito pareciera encarnar a través de esas modas "marginales" los criterios de rupturas de la moda profesional, ambos conceptos rivalizando y buscando su reacomodo en el mundo de la publicidad con la exacerbación de estéticas nómadas. 
Arribando a una desestabilización de códigos cuestionados, surge el cuerpo joven como mito en una cultura conformista, manifestándose en la apariencia de los sujetos jóvenes, pero también en los valores, gustos y comportamientos. Revela nuevos signos que han servido para mostrarse y narrarse en la cultura contemporánea del espectáculo. Barthes propone observar la moda dictando ley para jugar con sus receptores-consumidores y proclamar de mil maneras en revistas, poster, desfiles, cortos en pasarelas o vitrinas su ley como un espectáculo excesivo, un juego con su metáfora corporal haciendo unión con el poder; es un monarca de cargo hereditario que obliga como cualquier otra institución a los sujetos, decreta y prescribe o mezcla para crear esa ambivalencia en contra del tiempo moral. Los jóvenes la reciben y la asumen, pero constantemente también le dan su marca personal para alterarla y narrarse a su manera.

Una pieza relevante para el tema que nos ocupa es la minifalda, por su impacto en la cultura juvenil en los años sesenta (60) del siglo XX. Representó para las jóvenes un ícono de la liberación sexual, conmoviendo la moral judaico-cristiana y su pretensión de ocultar, la minifalda captura el auge de la moda a mediados del siglo XX. Masificada junto con la aparición de los Beatles y los Rolling Stones, se convirtió en un ícono durante toda esa época.

La minifalda se convirtió en un elemento provocador y seductor de las jóvenes mujeres para copar los espacios negados por la sociedad. Mostrar el cuerpo femenino con minifalda ayudó a desmitificar los prejuicios morales que lo conminaban a la vergüenza. El cuerpo joven se expone para narrar los nuevos signos de su inconformidad con la moral adormecida, tal vez distanciándose de las camisas de fuerza que le han impuesto, muestra tímidamente el imaginario del placer compartido de vivir plenamente su corporeidad.

Las partes del cuerpo femenino que deben mantenerse ocultas, ese lugar sagrado desde donde venimos al mundo, se acentúa con esta pieza corta y abierta, que apenas cubre dejando asomada la posibilidad de ver el misterio. Poderosa estrategia de seducción, que permite la libertad de movimiento, la exposición de las piernas, y rápidamente se incorpora a las imágenes de la publicidad. Progresivamente 
las vallas venderán su imagen, alguna vez transgresora. Para tensar a la sociedad con slogans, atuendos, y lenguajes de su corporeidad deseada y deseante.

La moda establece la simbología que ayuda a leer el cuerpo joven a través de una dialéctica del deseo que hurga, provoca, acorrala la moralidad. La minifalda se presenta como un imaginario del cuerpo joven que apunta a establecer la tensión de la finitud del cuerpo y otro que se desplaza hacia el imaginario de lo infinito.

Hoy día el cuerpo aparece intervenido, punzado, marcado, tatuado, eso que Fuenmayor (2007), denomina "grafiti corporal". Ya se reconoce que la minifalda a través de su propagación masiva en la moda y la publicidad ayudó a narrar el cuerpo joven, revelando un nuevo destino que mostraría la posibilidad de ser intervenido para exaltar los nuevos lenguajes del joven, relatado desde su corporeidad.

En ese orden de ideas, la categoría el cuerpo joven como mito permite abrir reflexiones en torno a que el cuerpo de los jóvenes pugna por mostrarse de manera creativa, dirigiéndose a límites insospechados. El joven coloca su acento en lo dúctil, informal, ya no canonizado, buscando otros horizontes estéticos en el tránsito de los cruces y lenguajes de manera lúdica, festiva, carnavalesca que habla y nos narra creativamente la corporeidad juvenil.

\section{Las sonoridades y el cuerpo joven}

Entendemos, con Cage (2002), a la música como sonidos y encontramos en las sonoridades a un individuo, o un grupo como una fuente de musicalidad.

A los seres humanos les asisten universos sonoros circundantes y la corporeidad individual es una fuente rítmico-melódica (que va desde los sonidos de la digestión o en el ritmo del corazón hasta la orquestación instrumental de una sinfonía); asunto ligado al ritmo de la vida de cada persona y colectivo.

Concebimos el cuerpo joven como mito en la construcción de sonoridades, del recurso ecológico que proporciona la naturaleza para la construcción de la música, es decir incorpora los sonidos sin pentagrama y se deslinda de las ataduras que esgrime la composición estructurada de la música, vista en la perspectiva de una antropología 
de las sonoridades nos acerca a la tensión de un imaginario del cuerpo joven como mito en la melodía.

La música modula, sintetiza y reproduce en diferentes grados sus propias dinámicas que, insertas en el cuerpo y a través de él, generan formas de sensibilidades. Se enuncia musicalmente o gestualmente en escenografías corporales juveniles, allí el cuerpo joven como mito se desplaza haciendo eco de expresiones estructurales simbolizando sus experiencias narradas, estéticas, nómadas, míticas.

Estamos en presencia de gestos sonoros. Prácticas de un sentir que trama expresividades emergentes del cuerpo joven, que a su vez se muestra como un texto visual, sonoro, gestual y mítico.

Cuerpos en disposición a, cuerpos a ser tocados por, cuerpos deseados, mirados, amados, destruidos. Cuerpos construidos por la publicidad, como una ilusión cambiante, metamorfoseados y que relampaguean en los imaginarios de cada uno de los participantes mediante la práctica de rituales, performances, gestos que ofrece el mundo del consumo.

Actualmente en las ciencias sociales y humanas se polemiza en torno a las relaciones de las culturas juveniles y sus manifestaciones en la modernidad. La polémica gira en torno a establecer de qué manera se exteriorizan y en qué dimensión práctica se simboliza esas expresiones corporales musicales, estéticas, tecnológicas.

Sobre este aspecto Reguillo (2000, p. 41), señala que: [...] la música, el habla, la apariencia estética, y las relaciones con la tecnología son ejes clave para entender los procesos de constitución del ‘yo’ en la modernidad tardía [...].

Esta autora reflexiona sobre la relación existente entre las identidades juveniles y la música en el contexto de una globalización de manera inexorable, devenida en la trasversalización de los espacios en donde se construyen, convive y se expresan las identidades sociales.

En síntesis, para esta autora es desde las identidades juveniles y sus prácticas, como áreas de problematización, donde se debe observar a los jóvenes y sus 
manifestaciones musicales. Resaltamos el valor de lo aportado por la autora por cuanto permite replantear la lectura de la cultura juvenil, enfatizando lo importante del enfoque etnográfico para dar cuenta de estas manifestaciones. La relación cultural con los jóvenes es vital para interpretar los cambios presentes en la sociedad del consumo.

Estas reflexiones muestran la posibilidad de vincular las sonoridades en la lectura del cuerpo joven como mito, sus corporeidades como el habla narrándose y expresándose míticamente a través de la música, entendidas por Cyrulnik (2008, p. 106), como un:

[...] habla etológica, corpórea, formada por... melodías, pautadas por silencios, en un contexto de mímicas faciales que expresan emociones verbales, gestos que subrayan o "contradicen", el discurso, y gestos que dan la palabra al espacio $[\ldots]$.

El cuerpo joven como mito adquiere una perspectiva de carácter autónomo que entrecruza las manifestaciones culturales y supera la concepción estrecha de analizarlo no solo desde la escritura del pentagrama mencionado anteriormente, sino que desde allí avanza hacia la otredad de géneros que practican los jóvenes.

El cuerpo joven como mito se lee como el sujeto vivo, un cuerpo con sentido a lo gestual, al ritual y a la sonoridad a través de múltiples realizaciones personales y colectivas del espacio de lo social. Asimila los desarrollos tecnológicos comunicacionales para exaltar la jovialidad, la imagen construida como eterna ilusión, una corporeidad narrada, que jamás perece.

Según Martín Barbero (1998, 47-48):

[...] La emergencia de fracturas culturales se hicieron visibles en los movimientos del 68 , de París a Berkeley pasando por ciudad de México. Entre lo que dicen los grafitis 'hay que explorar sistemáticamente el azar', 'la ortografía es una mandarina', 'la poesía está en la calle', 'la inteligencia camina más pero el corazón va más lejos' y lo que cantan los Beatlesnecesidad de liberar los sentidos, de explorar el sentir, de hacer estallar el sentido $[\ldots]$.

Desde las sonoridades surge "El Rock" tradicionalmente satanizado, caso emblemático del movimiento juvenil contracultural, reabsorbido por la cultura de masas. En los comentarios anteriores sobre el film de Godard (Simpatía por el Diablo), 
puede conducir a rastrear la construcción del cuerpo joven como mito en las sonoridades, revelando los ensambles realizados por grupos juveniles en las décadas de los años 60,70, del siglo XX, y de la influencia experimentada a través de los medios para crear expresiones estéticas nómadas; hacerse visibles, resignificando identidades culturales, las cuales se expresaron en rituales de violencia contestataria, rivalidades grupales, intervenciones corporales, apropiación de oralidades, hibridaciones sonoras, sincretismos instrumentales, interconexión de ritmos, implantes, tatuajes, cambios alimentarios, sexualidades, género, en la memoria que afianza, retrotrae y se encuentra con la diferencia cultural.

Además de una letra hereje y crítica, recordemos que en la canción Simpatía por el diablo, los Rolling Stones exhiben una rica tradición de ensamble. En el tema musical se muestra la tumbadora y el chequeré de raíces africanas, combinados con instrumentos acústicos y electrónicos. Es característica también la vestimenta habitual de los músicos y su ritual de destruir instrumentos en las performances públicas.

Para resignificar el mito del amor y las sonoridades en la juventud de migrantes caribeños hacia la populosa Nueva York por ejemplo en West Side Story (1961). Allí los musicales dirigidos a la población juvenil llenaban masivamente teatros, conciertos, cines. En estos espacios se muestran, menos reflexivos y de modo más inconsciente, el conflicto entre migrantes y nativos.

El musical en cuestión muestra las voces de los héroes juveniles migrantes enfrentando nuevos retos en la constitución de su identidad nómada, recuperando un antiguo conflicto presentado por Shakespeare en su trágico Romeo y Julieta (1599), ahora en las calles y barrios de Nueva York. Llama la atención la aceptación que tienen las letras musicales y melodías en las poblaciones juveniles tanto de Norteamérica como en otras ciudades del mundo. Ejemplo, María, América, o I Feel Pretty; les habla a los jóvenes de sus amores, desencantos, desigualdad y rivalidad grupal, vivida o soñada en cada Odisea violenta en la ciudad.

La crítica especializada del cine se mostró estremecida por cómo se caricaturizaba a la comunidad puertorriqueña de Nueva York. El amor imposible de Romeo y Julieta ahora en los barrios neoyorquinos, donde las familias Capuleto y 
Montesco son reemplazadas por dos bandas juveniles irreconciliables, los Jets, de clase obrera, y los puertorriqueños Sharks.

El discurso fílmico hollywoodense reafirma el artificio en la producción de los cuerpos expuestos, sacrificando la naturalidad de sus voces, de sus indumentarias, de sus gestos. Es la ciudad de Nueva York el espacio donde convergen los migrantes latinos, ahí en ese encuentro los cuerpos jóvenes buscan reacomodo para construir hibridez estética, nómada. Espacio emblemático de encuentro de sonoridades. El film nos permite reflexionar sobre este mestizaje con los aportes musicales, rítmicos, míticos vueltos un imaginario fílmico en las geografías corporales. Es el cuerpo mutante que se encuentra saturado de signos, gestos y miradas para compartir los lenguajes del otro. En este film los cuerpos se dejan erigir con ritmo y armonía construyendo un yo en el fuego amoroso del bolero, la rumba, el jazz latino, que juega con el chasquido de sus dedos, delimitando sus territorios sociales.

En West Side Story, la corporeidad de los jóvenes se muestra y narra en ritmos tropicales girados en la gran metrópoli. Como lenguajes se cruzan e intersectan cuerpos, tonos, gestualidades de la cultura urbana. Es como un texto cultural. Zavala en su texto sobre el bolero (2000) nos recuerda que son los primeros boleros (con el tango, el chachachá, el mambo) los que inician esa hibridez musical que parte desde las Antillas hacia el mundo y del mundo hacia las Antillas. Y son los cuerpos jóvenes los que se prestan desde sus superficies para intercambiar los signos de sus marcas, huellas, y coreografías rítmicas. La memoria amorosa se esfuerza en regresar a sus topias del afecto abandonadas en la ciudad de Puerto Rico. Ahí, se le canta al mar, al viento tropical y sus huracanados goces, los amores abandonados o los nuevos por venir. Son palabras, no se las lleva el viento, y en el film se van mostrando como motivo intertextual, un rio amoroso de cuerpos migrantes interceptados en las pasiones humanas.

Evocando aquella metáfora de la confluencia del rio Paraná de Lezama Lima (1968), en el film todo parece una desmesurada confusión, en ese espacio urbano urdido de ritmos, cuerpos y lenguajes las coreografías corporales de los jóvenes se abren como un horizonte estético. 
En su ficción, el cine nos esconde las profundas diferencias presentes en las simbolizaciones entre los humanos. La moda, las sonoridades nos llevan a identificar y leer la cultura juvenil subyacente en arquetipos juveniles, indiferenciados, ideales de la cultura urbana.

Era el temor que tenía Kafka cuando expresaba que el cine a través del ojo uniformizaba la vida.

\section{Referencias}

BAJTIN, M. (1926) Hacia una filosofía del acto ético y otros escritos. Barcelona: Anthropos, 1997.

BARTHES, R. (1967) El sistema de la moda y otros escritos. Barcelona: Paidós, 2003.

CAGE, J. Silencio: conferencias y escritos. Madrid: Ardora, 2002.

CALEFATO, P. Mass moda. En Traje, identidad y sujeto en el arte contemporáneo. [en línea]. Madrid: Ministerio de Cultura. Museo del Traje, 2007: 32-37. Disponible en red: <http://museodeltraje.mcu.es/ popups/publicaciones-electronicas/2007-TISAC/06-MT-TISAC-Calefato.pdf>. Consultado: 04 enero 2016.

CYRULNIK, B. Del gesto a la palabra: la etología de la comunicación en los seres vivos. Barcelona: Gedisa, 2008.

CORRADINI, L Estamos en la era de los nómades y las tribus, dice Maffesoli (Entrevista) Diario La Nación. Buenos Aires, 2005. Disponibel en red: <http://www.lanacion.com.ar/734590-estamos-en-laera-de-los-nomades-y-las-tribus-dice-maffesoli>. Consultado 04 enero 2016.

DELUMEAU, J. (1978). El miedo en occidente. Madrid: Taurus, 2002.

FOUCAULT, M. (1966) Las palabras y las cosas: una arqueología de las ciencias humanas. 4ta edición en español. México: Fondo de Cultura Económica, 1972.

FUENMAYOR, V. El cuerpo de la obra. Mérida: Universidad del Zulia: Editorial Venezolana, 2007.

GONZÁLEZ, J y GÓMEZ, R.F(r) Fricciones de cuerpos barrocos y opacos. Revista Educación y Pedagogía, Universidad de Antioquia. Facultad de Educación, vol., XII. Enero-Agosto.1999. p. 149-176.

HURTADO, E. Transparencia del signo. Caracas: Dirección de Cultura Universidad de Carabobo, 1973.

HILLMAN, J. (1972). Pan y la pesadilla. Barcelona: Atalanta, 2007

LEZAMA L., J. (1968) El reino de la imagen. Caracas: Biblioteca Ayacucho, 1981.

LIPOVETSKY, G. (1987) El imperio de lo efímero: la moda y su destino en las sociedades modernas. Barcelona: Anagrama, 2004.

LÓPEZ P., R. Hermes y sus hijos. Caracas: Ateneo de Caracas, 1980.

MAFFESOLI, M. El tiempo de las tribus. Siglo XXI. México: Fondo de Cultura Económica, 2004.

MARTÍN, B. J. Experiencia audiovisual y desorden cultural. En: Cultura, medios y sociedad. Bogotá: Panamericana, 1998. p. 27-64.

METZ. C. El decir y lo dicho en el cine: ¿hacia decadencia de un cierto verosímil? Lo Verosímil. Buenos Aires: Argentina, 1972. p 17-30.

MORIN, E. El cine o el hombre imaginario. Barcelona: Paidós, 2001.

REGUILLO, R. Emergencia de culturas juveniles. Estrategias del desencanto. Bogotá: Norma, 2000.

ZAVALA, I. El bolero: historia de un amor. Madrid: Celeste ediciones, 2000. 


\section{Otto Rosales Cárdenas}

Es doctor en Ciencias Humanas, Sociólogo y Antropólogo, catedrático de la Universidad de los Andes, Táchira- Venezuela. Entre sus líneas de investigación se destacan, oralidades, culturas juveniles, narrativas locales.

E-mail: ottorosca@gmail.com

Currículo: http://www.saber.ula.ve/bitstream/123456789/9356/2/orosales.pdf

\section{Stiver Machado Ramírez}

Es doctor en Ciencias Pedagógicas, del Instituto Pedagógico Latinoamericano y Caribeño (IPLAC). Lic. en Geografía y Ciencias de la Tierra. Entre sus líneas de investigación, Pedagogía alternativas, Cultura Musical Urbana, Culturas Juveniles.

E-mail: frankstivermachado@gmail.com

Recebido em 03 de março de 2017 Aceito em 17 de abril de 2017 